\title{
The Relative Impact of Various Grasshopper Species on Stipa-Agropyron Mixed Prairie and Fescue Prairie in Southern Alberta
}

\author{
J.M. HARDMAN AND S. SMOLIAK
}

\begin{abstract}
Sweep-net samples of grasshoppers were taken annually in late August at Stavely (1970-78) on Festuca scabrella prairie and at Coalhurst (1971-79) on Stipa-A gropyron prairie. Mean catches of grasshoppers were higher (170 vs 112 per 50 sweeps) and more species were sampled ( 27 vs 13) at Coalhurst. Melanoplus dawsoni (Scudder) was the dominant grasshopper at Stavely while Encoptolophus sordidus costalis (Scudder) and Melanoplus infantilis (Scudder) were codominants at Coalhurst. Grasshoppers were also sampled at two other sites in 1971 and one in 1971 and 1972 on Stipa-Agropyron prairie. Mean catches per 50 sweeps were 122, 164 , and 234, respectively, at these sites with 14,12, and 11 species of grasshoppers sampled. The dominant species were Ageneotettix deorum (Scudder), $M$. infantilis, and $M$. daw soni. Of the 35 species collected at the study sites, 21 , those forming at least $1 \%$ of the grasshoppers collected at one or more sites, were evaluated for their potential impact on rangeland. Population counts and published data on phenology, damage to rangeland, and feeding preferences were considered. The per capita feeding rate of adults-assumed to be proportional to the 0.68 power of body weight-was also assessed. Using these criteria, all but two species-Melanoplus femurrubrum femurrubrum (DeGeer) and $M$. dawsoni-were considered potentially damaging. Adult weights varied such that an adult $M$. infantilis, the smallest species, would feed at $\mathbf{2 8 \%}$ the rate of an adult Metator pardalinus (Saussure), the largest species. Published data on habitat preferences of the 21 species show that most of the damaging species prefer sparsely vegetated habitats and thus would be favored where range is overgrazed by cattle.
\end{abstract}

On the great plains of western North America, grasshoppers a re the most conspicuous and damaging insects on rangeland. They cause damage in three ways: by removal of forage in direct competition with livestock, by inducing permanent damage to the plants due to continued feeding beyond tolerable levels, and by destruction of seed heads, thus preventing natural reseeding (Hewitt 1977).

\footnotetext{
Authors are research scientists, Research Station, Agriculture Canada, Leth bridge, Alberta, Canada TIJ 4BI.

Dr. D.S. Smith, formerly of the Lethbridge Research Station, collected and identified grasshoppers in the earlier phases of this study. Dr. N.D. Holmes (retired) supervised collections and identifications until 1978. Mr. W.O. Nummi gave valuable assistance to Smith and Holmes as well as to the senior author.

Manuscript received August 20, 1980.
}

At any given site on native range, there may be more than $\mathbf{2 0}$ grasshopper species, each having a different potential for damaging the range. Five major factors-population density, feeding rate, phenology, feeding preference, and habitat preference-will determine this potential. Thus, other things being equal, the more abundant species will compete more seriously with cattle for rangeland vegetation. A high feeding rate also contributes to this competition. For instance, Putnam (1962a) measured feeding rates in field cages of adults of Camnula pellucida (Scudder) and Amphitornus coloradus coloradus (Thomas). Camnula pellucida reduced the grass yield by $95 \mathrm{mg} /$ grasshopper/day. Thus, a density of only 12.4 adults $/ \mathrm{m}^{2}$ would be equivalent to a grazing rate of $1 \mathrm{AUM} / \mathrm{ha}$, assuming a cow consumes $354 \mathrm{~kg}$ dry feed $/ \mathrm{mo}$. With $A$. coloradus, each adult destroyed $53 \mathrm{mg}$ of grass/day, so a density of 22.3 adults $/ \mathrm{m}^{2}$ of this species was equivalent to $1 \mathrm{AUM} / \mathrm{ha}$.

Grasshopper phenology is also important. Earlier developing species will graze at their maximum rate earlier in the season when forage grasses are actively growing. Grasshopper species preferring the same plants as cattle will be more serious competitors and have a greater economic impact than species that are general feeders or prefer weeds and shrubs. Grasshopper species that prefer open habitats with little cover will be favored in range overgrazed by cattle.

In this study, we examine these five factors in an attempt to compare the damage potential of the more abundant grasshopper species collected in the 1970's in southern Alberta from four sites on Stipa-Agropyron mixed prairie and one site on fescue prairie.

\section{Materials and Methods}

\section{Study Sites}

Four of the sites studied were representative of Stipa-Agropyron prairie in the Dark Brown soil zone. They were located near Coalhurst $(8 \mathrm{~km}$ west of Lethbridge), Pearce $(32 \mathrm{~km}$ west of Lethbridge), Spondin (190 km northeast of Calgary), and Provost (290 km northeast of Calgary) in southern Alberta. The fifth site studied was representative of fescue prairie in the Black soil zone and was located near Stavely ( $80 \mathrm{~km}$ northwest of Lethbridge).

The vegetation at the Coalhurst site was characterized by a dominance of Agropyron dasystachyum (Hook.) Scribn., A. smithii Rydb., and Stipa viridula Trin.; at Pearce and Spondin, $A$. dasystachyum, A. smithii, $S$. comata Trin. and Rupr., and $S$. 
spartea Trin. var. curtiseta Hitchc. were dominant; and at Provost, $S$ spartea var. curtiseta was dominant with some Festuca scabrella Torr. on north-facing slopes. Carex spp. were found in all stands, as was the forb Phlox hoodii Richards. Symphoricarpos occidentalis Hook. and Artemisia frigida Willd. were the most common shrubs. At the Stavely site, the vegetation was characterized by a dominance of $F$. scabrella and Danthonia parryi Scribn., associated with $F$. idahoensis Elmer, A. subsecundum (Link) Hitchc., and $S$. spartea var. curtiseta. Forbs included Geum triflorum Pursh, Galium boreale L., and Aster laevis L. and shrubs included Potentilla fruticosa, L., S. occidentalis, and Rosa spp.

\section{Estimates of Relative Abundance}

Grasshoppers were sampled annually in late August from StipaAgropyron prairie at Provost (1971-72), Coalhurst (1971-79, except 1977), Pearce (1977), and Spondin (1971), and from fescue prairie at Stavely (1970-78). The samples were obtained by making 50-1,000 semi-circular sweeps with a 34-cm diam. net at the rate of one sweep per step. More sweeps were taken when populations were low, fewer when populations were high as suggested by Gilbert (1973). In this study, all counts are reported as the average number caught per 50 sweeps. The grasshoppers were preserved in $70 \%$ ethanol and brought to the laboratory where they were counted and identified using Brooks' (1958) key.

\section{Estimates of Adult Feeding Rates}

Reichle (1968) examined feeding rates in 11 species of forest floor arthropods ranging in size from $2.1 \mathrm{mg}$ to $1.6 \mathrm{~g}$ live weight and including isopods, crickets, and millipedes. He found that

Table 1. Mean numbers of grasshoppers per 50 sweeps collected on StipaAgropyron prairie at Provost (1971-72) and Coalhurst (1971-79, excluding 1977) and on fescue prairie at Stavely (1970-78).

\begin{tabular}{|c|c|c|c|}
\hline \multirow{2}{*}{$\frac{\text { Species }}{\text { Melanoplus dawsoni (Scudder) }}$} & \multirow{2}{*}{$\frac{\text { Provost }}{138.50}$} & \multicolumn{2}{|c|}{ Coalhurst Stavely } \\
\hline & & 0.13 & 42.50 \\
\hline Camnula pellucida (Scudder) & 61.50 & 0.88 & 11.56 \\
\hline Chorthippus curtipennis (Harris) & 9.00 & 0.31 & 38.53 \\
\hline $\begin{array}{l}\text { Encoptolophus sordidus costalis } \\
\text { (Scudder) }\end{array}$ & 10.25 & 30.17 & 0 \\
\hline Melanoplus infantilis (Scudder) & 8.25 & 28.94 & 1.11 \\
\hline Melanoplus sanguinipes (Fabr.) & 1.00 & 18.71 & 7.08 \\
\hline Ageneotettix deorum deorum (Scudder) & 0 & 22.84 & 0 \\
\hline $\begin{array}{l}\text { Amphitornus coloradus coloradus } \\
\text { (Thomas) }\end{array}$ & 0 & 19.83 & 0 \\
\hline $\begin{array}{l}\text { Phlibostroma quadrimaculatum } \\
\text { (Thomas) }\end{array}$ & 0 & 13.50 & 0 \\
\hline Melanoplus gladstoni (Scudder) & 0.25 & 7.44 & 2.67 \\
\hline Aeropedellus clavalus (Thomas) & 2.00 & 4.19 & 2.81 \\
\hline Melanoplus bivittatus (Say) & 1.00 & 0.76 & 3.72 \\
\hline Phoetaliotes nebrascensis (Thomas) & 0 & 4.81 & 0 \\
\hline $\begin{array}{l}\text { Arphia pseudonietana pseudonietana } \\
\text { (Thomas) }\end{array}$ & 1.00 & 3.63 & 0 \\
\hline Metator pardalinus (Saussure) & 0 & 4.32 & $\mathbf{0}$ \\
\hline Bruneria brunnea (Thomas) & $\mathbf{0}$ & 4.31 & 0 \\
\hline Aulocara ellionti (Thomas) & 0 & 2.81 & 0 \\
\hline Neopodismopsis abdominalis (Thomas) & 0 & 0 & 1.50 \\
\hline Melanoplus packardii (Scudder) & 0 & 1.00 & 0 \\
\hline Trimerotropis campestris (McNeill) & 0.75 & 0.06 & 0 \\
\hline Aulocara femoratum (Scudder) & 0 & 0.63 & 0 \\
\hline $\begin{array}{l}\text { Psoloessa delicatula delicatula } \\
\text { (Scudder) }\end{array}$ & $\mathbf{0}$ & 0.63 & 0 \\
\hline $\begin{array}{l}\text { Melanoplus femurrubrum femurrubrum } \\
\text { (DeGeer) }\end{array}$ & 0 & 0.31 & 0 \\
\hline Melanoplus oregonensis (Thomas) & 0 & 0.13 & 0.17 \\
\hline Xanthippus corallipes Haldeman & 0 & 0 & 0.22 \\
\hline Trachyrhachys kiowa kiowa (Thomas) & $\mathbf{0}$ & 0.19 & 0 \\
\hline Spharagemon equale (Say) & $\mathbf{0}$ & 0.13 & $\mathbf{0}$ \\
\hline Melanoplus bruneri (Scudder) & 0 & 0 & 0.11 \\
\hline Melanoplus foedus (Scudder) & $\mathbf{0}$ & $\mathbf{0}$ & 0.06 \\
\hline Derotmema haydenii haydenii (Thomas) & 0 & 0.06 & $\mathbf{0}$ \\
\hline Tetrix sp. & 0 & 0.06 & 0 \\
\hline Total & 233.50 & 170.33 & 112.12 \\
\hline
\end{tabular}

feeding rate was proportional to the $\mathbf{0 . 6 8}$ power of body weight. In this study, we assumed the same relationship applies to grasshoppers and that feeding rates of different species can be compared if body weights are known.

Weights of adults were from specimens collected by sweep-net in August 1979 from the Coalhurst study site (most species labelled ' $a$ ' in Table 6) and from roadsides (b in Table 6) near spring wheat at the northeast corner of Lethbridge County. There were three exceptions: $M$. pardalinus (Saussure) was collected in 1976 at Coalhurst, and Melanoplus dawsoni was collected in 1979 and $C$. curtipennis in 1976 at the Stavely study site. (Full names of grasshopper species and authorities are listed in Table 1.) Where too few insects were available for weighing, data were taken from the literature (c, $d$, and $e$ in Table 6).

Usually, fresh specimens were stored at $-40^{\circ} \mathrm{C}$, dried 72 hours at $70^{\circ} \mathrm{C}$, and then weighed. Metator pardalinus and $C$. curtipennis were stored 3 years in $70 \%$ ethanol before being dried and weighed. The ovendry weight was assumed to be 1.669 times the 'alcohol'dry weight as this was the appropriate mean correction factor for adults of several rangeland grasshoppers studied in Saskatchewan (Riegert and Varley 1973a).

\section{Results and Discussion}

\section{Numbers Sampled}

Mean numbers of each species per 50 sweeps at Provost, Coalhurst, and Stavely are listed in Table I. Species are ranked in order of overall abundance giving equal weight to each site. The three most abundant species were $M$. dawsoni, $C$. pellucida, and $C$. curtipennis. the mean catch of grasshoppers varied from 112 at Stavely to 233 at Provost.

At Provost, a total of 934 grasshoppers of 11 species were collected: $M$. dawsoni, $C$. pellucida, and $E$. sordidus accounted for 90\% of the total. At Coalhurst, $E$. sordidus, $M$. infantilis, and $\boldsymbol{A}$. deorum comprised $48 \%$ of the 2,796 grasshoppers (27 species) collected. At Stavely, $83 \%$ of the 1,603 grasshoppers (13 species) collected were $M$. dawsoni, $C$. curtipennis, and $C$. pellucida.

In 1971, samples were also taken at Pearce and Spondin where the catches were, respectively, 122 and 165 grasshoppers. Of the 14 species sampled at Pearce, two-A. deorum and A. elliotti-comprised $65 \%$ of the 260 grasshoppers collected (Table 2). At Spondin, 12 species were sampled with $M$. infantilis and $A$. clavatus comprising $73 \%$ of the 330 grasshoppers collected. The mean catch (164.5) was higher than those from Coalhurst (133.5), Provost (108), and the fescue prairie at Stavely (82.5).

At Coalhurst (Fig. 1), the total grasshopper catch showed a gradual rise (1971-1974) followed by a pronounced decline in the late 1970 's. This pattern also applied to the three most abundant species and the total catch for the remaining 23 species. At Stavely, there was a pronounced peak in 1974 for the total catch as well as

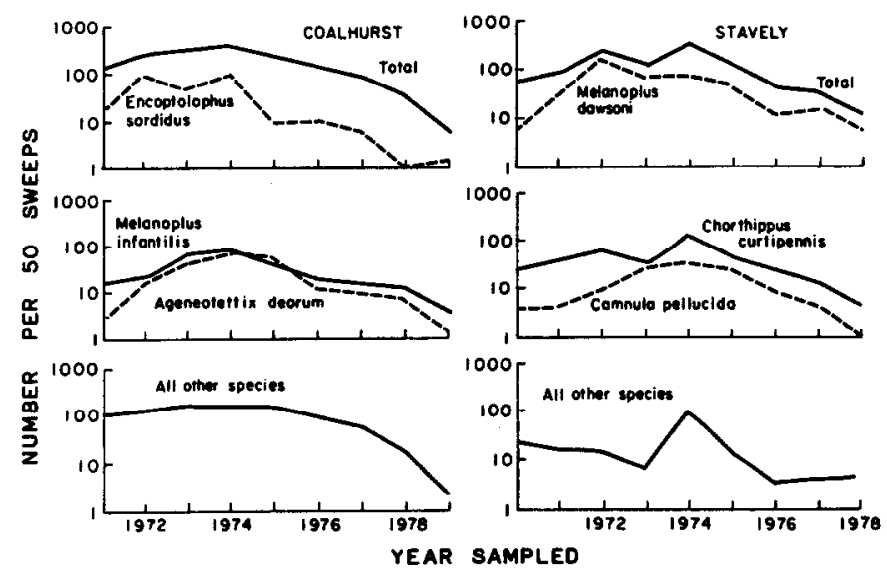

Fig. 1. Numbers caught per 50 sweeps for the total grasshopper population. the three most abundant species, and for the remaining species. Values for 1977 at Coalhurst are interpolations between 1976 and 1978. 
for $C$. curtipennis and the total catch for the 10 less-abundant species. There was also a decline in the late 1970 's though it was less pronounced than at Coalhurst.

\section{Phenology, Diet, and Habitat Preferences}

In the following two sections, we examine published data on the phenology, feeding preferences, habitat preferences, and adult weights of the more abundant grasshoppers, i.e., those comprising at least $1 \%$ of the catch from at least one of the study sites. These 21 species appear in Tables 3-6. With this information, we then compare the relative impacts of the different species.

Newton et al. (1954) examined the phenology of grasshoppers in eastern Montana and classified the species as early, intermediate, and late-season developers. Early species were those hatching before mid-May for the sea sons of 1950 and 1951. Hatching began after mid-May with intermediate species. With late-season species, dates of earliest hatch were during or after mid-June.

Species in Table 3 are listed in phenological sequence from the earliest hatching to the latest hatching. Of the six early season species, only $M$. bivittatus was not mentioned as damaging rangeland. This species is a mixed feeder subsisting on both grasses and forbs. The others are either obligate grassfeeders or prefer grasses (C. pellucida). Among the eight intermediate developers, only two-M. femurrubrum and $C$. curtipennis-have not been noted for damaging rangeland. The latter does, however, prefer grasses and the lack of reported cases of damage may be due to low numbers rather than its feeding habits. Melanoplus sanguinipes and $M$. packardii, mixed feeders, have been noted as occasionally destructive. The other species, all of which can be damaging, are grass feeders. Only three of the seven late developers were noted as damaging but it may be suspected with the two Arphia species and with $M$. gladstoni that there is the potential for damage should numbers get high; all three prefer grasses. Melanoplus dawsoni has not been listed as damaging and is listed as a mixed feeder preferring forbs.

Table 2. Mean number of grasshoppers collected per 50 sweeps in 1971.

\begin{tabular}{|c|c|c|c|c|c|}
\hline Species & $\begin{array}{l}\text { Coal- } \\
\text { hurst }\end{array}$ & Stavely & Pearce & Spondin & $\begin{array}{l}\text { Pro- } \\
\text { vost }\end{array}$ \\
\hline M. infantilis & 15.5 & 0 & 0 & 104.5 & 4.5 \\
\hline M. dawsoni & 1.0 & 31.5 & 0 & 2.5 & 86.0 \\
\hline A. deorum & 1.5 & 0 & 66.5 & 0 & 0 \\
\hline C. curtipennis & 2.0 & 34.5 & 0 & 0 & 9.0 \\
\hline M. gladstoni & 41.5 & 0 & 0 & 0 & 0 \\
\hline E. sordidus & 15.5 & 0 & 0.5 & 12.0 & 0 \\
\hline A. clavatus & 0 & 0 & 8.0 & 15.0 & 1.5 \\
\hline C. pellucida & 0 & 3.0 & 8.5 & 6.5 & 3.5 \\
\hline M. bivittatus & $\mathbf{0}$ & 9.0 & 9.0 & 0 & 0.5 \\
\hline T. kiowa & 0 & 0 & 4.0 & 12.0 & 0 \\
\hline M. sanguinipes & 10.0 & 0 & 4.5 & 0.5 & 0 \\
\hline B. brunnea & 12.0 & 0 & 0 & 2.5 & 0 \\
\hline A. coloradus & 12.5 & $\mathbf{0}$ & 1.5 & 0 & 0 \\
\hline A. elliotti & 0 & 0 & 12.5 & 0 & 0 \\
\hline A. pseudonietana & 7.5 & 0 & 0 & 0 & 1.5 \\
\hline P. quadrimaculatum & 8.5 & 0 & 0 & 0 & 0 \\
\hline M. packardii & 0.5 & 0 & 5.0 & $\mathbf{0}$ & 0 \\
\hline M. femurrubrum & 0 & $\mathbf{0}$ & 0 & 5.5 & 0 \\
\hline P. nebrascensis & 4.0 & 0 & 0 & 0 & 0 \\
\hline M. pardalinus & 1.5 & 0 & 0.5 & 1.0 & 0 \\
\hline T. campestris & 0 & $\mathbf{0}$ & 0 & 1.0 & 1.5 \\
\hline$X$. corallipes & 0 & 2.0 & 0 & 0 & 0 \\
\hline N. abdominalis & 0 & 2.0 & 0 & 0 & \\
\hline M. kennicottil & 0 & 0 & 0 & 1.5 & 0 \\
\hline M. oregonensis & $\mathbf{0}$ & 0.5 & 0 & 0 & 0 \\
\hline A. conspersa ${ }^{I}$ & $\mathbf{0}$ & 0 & 0.5 & 0 & 0 \\
\hline H. viridis ${ }^{l}$ & 0 & $\mathbf{0}$ & 0.5 & 0 & 0 \\
\hline S. collare ${ }^{I}$ & 0 & 0 & 0.5 & 0 & 0 \\
\hline Total & 133.5 & 82.5 & 122.0 & 164.5 & 108.0 \\
\hline
\end{tabular}

'Full names are Phoetaliotes nebrascensis (Thomas), Melanoplus kennicotti Scudder, Arphia conspersa Scudder, Hesperotetrix viridis pratensis Scudder, and Spharagemon collare (Scudder).
Table 3. Phenology, damage potential or damage reported, and general feeding preferences of the more abundant species of grasshoppers collected at the five study sites. Species are shown in phenological sequences.

\begin{tabular}{|c|c|c|c|}
\hline & $\begin{array}{l}\text { Months when } \\
\text { eggs hatch (j) }\end{array}$ & $\begin{array}{l}\text { Damaging to } \\
\text { rangeland }\end{array}$ & $\begin{array}{c}\text { Feeding preference } \\
\text { (References) }^{\prime}\end{array}$ \\
\hline \multicolumn{4}{|c|}{ Early developers } \\
\hline A. clavatus & May & $\mathrm{d}, \mathrm{e}, \mathrm{g}, \mathrm{i}, \mathrm{k}$ & $\begin{array}{l}\text { Grasses } \\
(a, b, e, i)\end{array}$ \\
\hline A. elliotti & May-June & $b, d, g, i, m$ & $\begin{array}{c}\text { Grasses } \\
(\mathrm{a}, \mathrm{b}, \mathrm{e}, \mathrm{f}, \mathrm{h}, \mathrm{i})\end{array}$ \\
\hline A. coloradus & May-June & $\mathrm{d}, \mathrm{g}$ & $\begin{array}{c}\text { Grasses } \\
(\mathrm{a}, \mathrm{b}, \mathrm{e}, \mathrm{f}, \mathrm{h}, \mathrm{i}, \mathrm{l})\end{array}$ \\
\hline M. bivittatus & May-June & - & $\begin{array}{c}\text { Mixed } \\
(b, e, f, h, i)\end{array}$ \\
\hline C. pellucida & May-June & $\mathrm{d}, \mathrm{g}$ & $\begin{array}{c}\text { Mixed, prefers } \\
\text { grasses } \\
(\mathrm{a}, \mathrm{e}, \mathrm{f})\end{array}$ \\
\hline A. deorum & May-June & $\mathrm{g}, \mathrm{i}$ & $\begin{array}{c}\text { Grasses } \\
\text { (a,b,e,f,h,i,k) }\end{array}$ \\
\hline \multicolumn{4}{|c|}{ Intermediate developers } \\
\hline M. infantilis & May-June & $b, g$ & $\begin{array}{c}\text { Grasses } \\
(\mathrm{a}, \mathrm{b}, \mathrm{f}, \mathrm{h}, \mathrm{i})\end{array}$ \\
\hline M. sanguinipes & May-June & $d, g, i$ & $\begin{array}{c}\text { Mixed } \\
(a, b, e, f, h)\end{array}$ \\
\hline B. brunnea & June & $d, k$ & $\begin{array}{c}\text { Grasses } \\
(a, e, f)\end{array}$ \\
\hline M. packardii & June & g & $\begin{array}{c}\text { Mixed prefers } \\
\text { forbs } \\
(\mathbf{a}, \mathbf{b}, \mathrm{e}, \mathrm{f}, \mathrm{i})\end{array}$ \\
\hline M. pardalinus & June & b & $\begin{array}{l}\text { Grasses } \\
(a, b, e, f)\end{array}$ \\
\hline T. kiowa & June-July & d.g & $\begin{array}{c}\text { Grasses } \\
(a, b, e, f, h, i, l)\end{array}$ \\
\hline$M$. femurrubrum & June-July & - & $\begin{array}{l}\text { Mixed } \\
(b, e, f, i)\end{array}$ \\
\hline C. curtipennis & June-July & - & Grasses \\
\hline
\end{tabular}

(e)

Late developers

P. quadrimacularum June-July f,g,i

A. pseudonietana June-July

Grasses

$(a, b, e, f, h, i)$

Mixed, prefers grasses (b,e,h,i)

$M$. dawsoni June-July $\quad-\quad$ Mixed prefers forbs $(\mathbf{a}, \mathrm{b}, \mathrm{e}, \mathrm{f}, \mathrm{i})$

E. sordidus June-July $\quad g \quad \begin{gathered}\text { Grasses } \\ (\mathrm{b}, \mathrm{c}, \mathrm{d}, \mathrm{e}, \mathrm{f}, \mathrm{h}, \mathrm{i})\end{gathered}$

$P$. nebrascensis June-July b,g,i

Mixed, prefers grasses

(a,b,e,f,h,i)

M. gladstoni July - $\quad$ Mixed, prefers grasses (b,e,f,i)

A. conspersa August

Mixed, prefers grasses $(\mathrm{e}, \mathrm{g}, \mathrm{h}, \mathrm{i}, \mathrm{l})$

Ia-Anderson (1964), b-Anderson and Wright (1952), c-Bailey and Riegert (1971), d-Beirne (1972), e-Brooks (1958), f-Criddle (1933), g-Hewitt (1977), h-Isley (1944), i-Mulkern et al. (1969), j-Newton et al. (1954), k-Riegert (1968), I-Ueckert et al. (1972), $\mathrm{m}-$ White and Rock (1945).

Mulkern et al. (1969) used data from crop content analyses to determine the degree of preference for grasses and forbs ('grassforb' index) and assigned forage values for cattle to the plants eaten by grasshoppers (Table 4). They determined the grass-forb index by subtracting the percent of a grasshopper species with grasses or sedges in its crop from the percent with forbs. This index may range from -100 for an exclusive grass feeder to +100 for species that subsists solely on forbs. If the index is the same at various sampling sites, one may suspect that feeding habits do not change with 
changes in vegetation while a variable index suggests a more opportunistic response.

Mulkern et al. (1969) then determined a 'plant value' index for each grasshopper species by multiplying the percentage of individuals with a particular plant in their crop by the forage value of that plant species for cattle. The sum of the products for all plants in the diet equals the plant value index, which may range from 0 to 90 . The higher this index, the more valuable are the food plants ingested by the grasshopper.

Four of the early season developers (Table 4) have strongly negative grass-forb indices indicating a strong preference for grasses while their high plant value indices show a preference for the more valuable forage species. Camnula pellucida also prefers the more valuable forage species (Putnam 1962b; references in Table 3). At one study site, $M$. bivittatus showed a preference for grasses and at three sites it had moderately high plant value indices.

In the intermediate group, only $M$. infantilis and $T$. kiowa had negative grass-forb indices and consistently high plant value indices. At two of the four sites, $M$. sanguinipes showed a preference for grasses and at two sites, it had high plant value indices. Mulkern et al. (1969) did not report the feeding preferences of $B$. brunnea, $M$. pardalinus, and C. curtipennis but other authors (refs. in Table 3) note them as preferring grasses. Melanoplus packardii was largely a forb feeder at the two sites where it was collected, and at Scott's Bluff, Nebraska, it had an intermediate plant value index (43). Melanoplus femurrubrum was also a forb feeder but it had a moderate plant value index at one study site.

Five of the seven late season species had strong negative grassforb indices and preferred the more valuable species of plants. At one site, $M$. gladstoni showed a definite preference for grasses and preferred the more valuable plant species. Melanoplus dawsoni seemed to be the only innocuous species preferring forbs to grasses and preferring less valuable forage plants.

Anderson (1964) monitored plant cover by the point-quadrat method and estimated grasshopper densities by sweep-net sampling and bottomless cages at 105 grassland sites in eastern Mon- tana. Areas where densities exceeded 1 grasshopper $/ \mathrm{m}^{2}$ were classified as occupied. The percent foliage cover of habitats favored by the grasshopper species is shown in the final column of Table 4. Low percentages and a narrow range in percent foliage cover indicate a strict requirement for open ground while a broader range of percent cover indicates tolerance for denser growth as well as sparsely vegetated locations. Melanoplus bivittatus tolerated a broad range of situations (up to $80 \%$ cover) and $A$. clavatus was found in habitats having up to $60 \%$ cover but the other early season species preferred sites with less than $41 \%$ cover. With the intermediate developers, $M$. sanguinipes tolerated a wide range of situations, while $M$. infantilis, B. brunnea, M. packardii, and $T$. kiowa required somewhat more open ground (0-60\% cover). Metator pardalinus did not occupy habitats having more than $20 \%$ cover. With the late developers, Phoetaliotes nebrascensis occupied habitats having up to $60 \%$ plant cover while Phlibostroma quadrimaculatum and $M$. dawsoni occupied more open situations.

A strong indication of damage potential would be a demonstrated preference for those species of plants that provide good forage for cattle (Smoliak et al. 1976) and are dominant at the study site. Clarke et al. (1942) used the point-count method to estimate the percent vegetational cover for the dominant plant species on Stipa-Agropyron prairie at three sites in Saskatchewan and one in Alberta. The dominant grasses (good forage) were (\% ground cover in brackets): $S$. spartea var. curtiseta (1.8), A. smithii (1.6), Bouteloua gracilis (H.B.K.) Lag. (1.4), Koeleria cristata (L.) Pers. (1.0), S. comata (0.8), A. dasystachyum (0.8), $F$. scabrella (0.7), Poa secunda Presl.(0.2), A. subsecundum (0.1), and Danthonia intermedia Vasey (0.1). Dominant sedges (good cattle forage) were Carex heliophila Mack. (3.1) and $C$. filifolia Nutt. (0.2). The shrubs vary from poor forage, $A$. frigida (2.1), to fair, $A$. cana Pursh (0.02), to good, Eurotia lanata (Pursh) Mog. (0.02) and Atriplex nuttallii S. Wats. (0.1). The dominant forb, $P$. hoodii (0.5) is poor forage. Johnston et al. (1971) listed the average percent basal area for the dominant plants on a moderately grazed field at Stavely. The dominant grasses (good forage) were $F$. scabrella

Table 4. Grass-forb indices, plant value indices, and percentage foliage cover of favored habitats for the more abundant grasshopper species.

\begin{tabular}{|c|c|c|c|c|c|c|c|c|c|}
\hline \multirow[b]{3}{*}{ Species } & \multirow{2}{*}{\multicolumn{4}{|c|}{ Grass-forb }} & \multirow{2}{*}{\multicolumn{4}{|c|}{ Plant value }} & $\begin{array}{c}\text { Favored } \\
\text { habitat }^{2}\end{array}$ \\
\hline & & & & & & & & & $\%$ total \\
\hline & $\mathbf{K}$ & NP & SB & $\overline{N D}$ & $\mathbf{K}$ & NP & $\mathbf{S B}$ & $\overline{N D} f$ & liage cover \\
\hline \multicolumn{10}{|c|}{ Early developers } \\
\hline $\begin{array}{l}\text { A. clavatus } \\
\text { A. elliotti }\end{array}$ & & -92 & -100 & & & 77 & 73 & & $\begin{array}{l}0-00 \\
0-40\end{array}$ \\
\hline A. coloradus & & -100 & -100 & -100 & & 71 & 72 & 74 & $0-20$ \\
\hline M. bivittatus & 7 & 28 & -50 & 24 & 61 & 16 & 54 & 43 & $0-80^{3}$ \\
\hline C. pellucida & & & & & & & & & $0-40^{3}$ \\
\hline A. deorum & -100 & -100 & -100 & -91 & 87 & 69 & 78 & 71 & $0-40$ \\
\hline \multicolumn{10}{|c|}{ Intermediate developers } \\
\hline M. infantilis & & & -95 & & & & 76 & & $0-60$ \\
\hline$M$. sanguinipes & 3 & 18 & -5 & -14 & 77 & 23 & 39 & 50 & $0-80$ \\
\hline B. brunnea & & & & & & & & & $0-60$ \\
\hline M. packardii & & 84 & 13 & & & 18 & 43 & & $0-60$ \\
\hline M. pardalinus & & & & & & & & & $0-20$ \\
\hline T. kiowa & & -100 & -100 & -100 & & 79 & 77 & 85 & $0-60$ \\
\hline M. femurrubrum & 38 & 86 & & 14 & 32 & 3 & & 43 & \\
\hline \multicolumn{10}{|c|}{ Late developers } \\
\hline P. quadrimaculatum & & -100 & -100 & & & 79 & 76 & & $0-40$ \\
\hline A. pseudonietana & & -100 & & -100 & & 80 & & 82 & \\
\hline M. dawsoni & & & & 33 & & & & 40 & $0-20$ \\
\hline E. sordidus & & & & -96 & & & & 70 & \\
\hline P. nebrascensis & -93 & -92 & & -66 & 68 & 66 & & 52 & $0-60$ \\
\hline M. gladstoni & & & -25 & 34 & & & 60 & 41 & \\
\hline A. conspersa & & -100 & & -78 & & 61 & & 67 & \\
\hline
\end{tabular}

'Samples for the grass-forb and plant value indices were collected by Mulkern et al. (1969) at study sites in Kansas (K); North Platte (NP), and Scott's Bluff (SB), Nebraska; and North Dakota (ND)

2Based on studies by Anderson (1964).

${ }^{3}$ Species collected only at abandoned field sites (Anderson 1964). 
(4.9), D. parryi (4.0), and F. idahoensis (1.3). Other grasses totalled 3.6\%. Prominent among these were Poa spp., $A$. dasystachyum, $K$. cristata, Bromus pumpcllianus Scribn., S. spartca, and A. subsecundum (fair to good) with $S$. viridula and Calamagrostis montanensis Scribn. forming minor elements of the complex. Carex spp. (good forage) totalled only $0.8 \%$ while forbs and shrubs (at best fair forage) totalled $6.6 \%$.

Hewitt (1977, appendix table 1), drawing on several published works, listed the preference food plants of economic species of rangeland grasshoppers. Table 5 , derived in part from his table, shows that 19 of the 21 more abundant grasshopper species preferred plants that were important elements of the vegetation at the study sites and were good forage for cattle. Admittedly, with $M$. packardii, Bouteloua gracilis was not listed as a preferred food but, of the 88 specimens collected at Scott's Bluff, Nebraska (Mulkern et al. 1969), 24\% had Bouteloua gracilis in their crop. Only $M$. femurrubrum and $M$. dawsoni were not listed as preferring important forage species from the study site where they were collected. Another dimension to feeding preference is inclusion of dried plant material and plant debris in the diet (Anderson and Wright 1952). Species that occasionally supplement their diet with dried material are denoted by a superscript 2 in Table 5 . Those which feed heavily on dried matter both as nymphs and adults are denoted by superscript 3. At first glance, feeding on dried material seems to be less important than feeding on green vegetation, but harm does ensue (Hewitt 1977). The direct effect is removal of cured forage for cattle. Storage reserves for perennial grasses may be reduced, particularly if feeding reaches the crown. Removal of the standing dead material and litter alters microclimate to the detriment of the grasses and to the advantage of forbs and grasshoppers. Erosion is encouraged. In addition, seedfeeders, such as $A$. deorum, inhibit natural regeneration of the range.

\section{Feeding Rate}

Relative feeding rates were assumed to be proportional to the 0.68 power of body weight. Those for males and females are expressed as percentages of the value for female $M$. pardalinus, the largest grasshopper collected at the study sites. The final column in Table 6 is the mean of the percentage for males and females (preceding two columns) divided by the mean relative feeding rate for $M$. paradlinus. The smallest of the grasshoppers were $M$. infantilis $(40.16 \mathrm{mg})$, which were estimated to feed at $28 \%$ of the
Table 5. Dominant forage plants at the study sites that were preferred by the more abundant grasshoppers.

\begin{tabular}{|c|c|c|}
\hline Species & Preferred plants & References $^{\prime}$ \\
\hline $\begin{array}{l}\text { A. clavatus } \\
\text { A. elliotti } \\
\text { A. coloradus } \\
M . \text { bivittatus } \\
C . \text { pellucida } \\
\text { A. deorum }\end{array}$ & $\begin{array}{c}\text { Early developers } \\
\text { C.f., K.c., P.s. } \\
\text { A., A.s., B.g., P.s., S.c. } \\
\text { A., A.s., B.g., P.s., S.c. }{ }^{2} \\
\text { A.s., B.g., S.c. }{ }^{2} \\
\text { C., F.i., K., P.s., S. } \\
\text { A.s., B.g., P.s., S.c. }{ }^{2}\end{array}$ & $\begin{array}{l}\text { d } \\
\text { a,d } \\
d \\
\text { e } \\
\text { d } \\
d\end{array}$ \\
\hline $\begin{array}{l}\text { M. infantilis } \\
\text { M. sanguinipes } \\
\text { B. brunnea } \\
\text { M. packardï } \\
\text { M. pardalinus } \\
T . \text { kiowa } \\
\text { M. femurrubrum } \\
\text { C. curtipennis }\end{array}$ & $\begin{array}{c}\text { Intermediate developers } \\
\text { A.s., B.g., C.f. } \\
\text { A.s., B.g., P.s. } \\
\text { A., B., C., K., S. } \\
\text { Art., B.g. }{ }^{3} \\
\text { A., A.s., C., S.2 } \\
\text { A., A.s., B.g., P.s. }{ }^{2} \\
-2{ }^{2} \\
\text { A., C., K. }\end{array}$ & $\begin{array}{c}\text { d } \\
\text { d } \\
\text { b } \\
\text { a, d,e } \\
\text { a, b,c } \\
\text { d } \\
\text { b }\end{array}$ \\
\hline $\begin{array}{l}P . \text { quadrimaculatum } \\
\text { A. pseudonietana } \\
\text { M. dawsoni } \\
\text { E. sordidus } \\
P . \text { nebrascensis } \\
M . \text { gladstoni } \\
\text { A. conspersa }\end{array}$ & $\begin{array}{c}\text { Late developers } \\
\text { B.g. } \\
\text { A., A.s., K., K.c. } \\
- \\
\text { A.s., B.g., P.s. } \\
\text { A.s., P.s. } \\
\text { A.s., B.g. } \\
\text { A., C., C.f., K.c., S., S.c. }\end{array}$ & $\begin{array}{c}\text { d } \\
a, b, c, e \\
d \\
d \\
a, c \\
b, e\end{array}$ \\
\hline
\end{tabular}

'a-Anderson and Wright (1952), b-Brooks (1958), c-Criddle (1933), d-Hewitt (1977), e-Mulkern et al. (1969).

A.-Agropyron sp., Art.-Artemisia sp., A.s.-Agropyron smithii, B.-Bouteloua sp., B.g.-Bouteloua gracilis, C.-Carex sp., C.f.-Carexfilifolia, F.i.-Fesinca illahversis, K.Koeleria sp., K.c.-Koeleria cristata, P.s.-Poa secunda (Syn. Poa sandbergii), S.-Stipa sp., S.c.-Stipa comata.

2Supplements diet with plant debris and dried plant material (Anderson and Wright 1952).

3Dry material forms a substantial part of the diet for nymphs and adults (Anderson and Wright 1952).

rate predicted for $M$. pardalinus. We have already noted that adult C. pellucida at a density of 12.4 grasshoppers $/ \mathrm{m}^{2}$ would exert a grazing pressure of 1 AUM/ha (Putnam 1962a). Assuming that Table 6 is a valid comparison of the different species, we can

Table 6. Dry weight of adults (number weighed in brackets) and estimated feeding rates relative to female $M$. pardalinus (columns 8,9) and to the average for both sexes of $M$. pardalinus (final column).

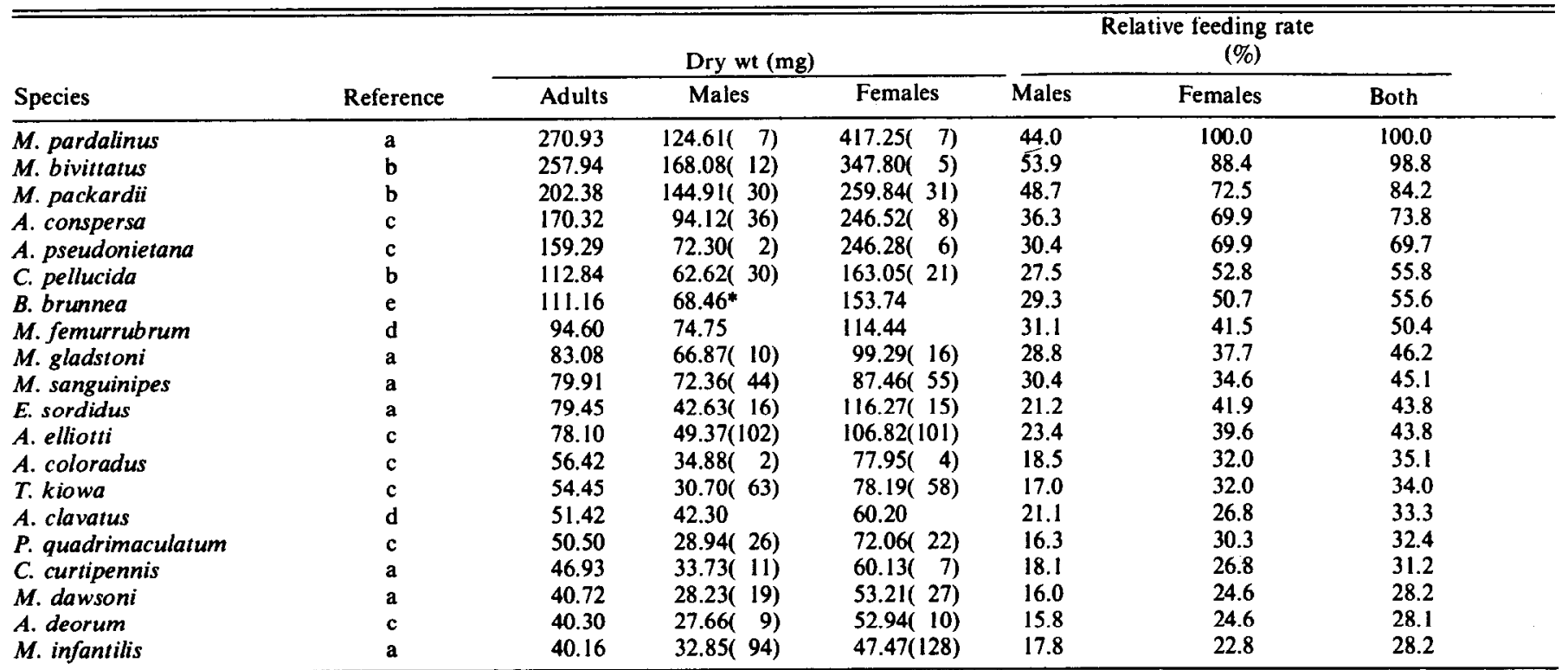

a-collected from rangeland; b-collected from cropland; c-Bhatnagar and Pfadt (1973); d-Riegert and Varley (1973a); e-Riegert and Varley (1973b).

* Sample size not listed in references $d$ and $e$. 
calculate that a density of only $6.9 \mathrm{M}$. pardalinus $/ \mathrm{m}^{2}$ would graze at the same rate, whereas the density of $M$. infantilis adults would have to be $24.6 / \mathrm{m}^{2}$ to graze at a rate of $1 \mathrm{AUM} / \mathrm{ha}$.

Table 6 should be interpreted with caution. The degree of sclerotization varies among the species Some, such as $M$. pardalinus and the Arphia species, are heavily armoured relative to others such as $C$. pellucida. This would affect the relationship between weight and feeding rate. The feeding rate of individuals varies with their age within an instar and this is particularly true for adults as they pass through different phases of their reproductive cycle (Parker 1930). The reproductive status of females in Table 6 was not known. Finally, several factors, including mode of feeding, e.g., at the tip of the leaf or base of the stem (Anderson and Wright 1952), the degree of preference for a particular plant (Mitchell 1973), the size of the jaws of the grasshopper relative to the width of the blade or stem, and the ratio of stem or blade height to width (Mitchell 1973, Mitchell and Pfadt 1974, Mukerji et al. 1976), determine the ratio of material that is clipped to that which is eaten. The destructiveness of a grasshopper depends as much on its clipping rate as on its feeding rate. Nonetheless, Table 6 does give some indication of the relative impact of different species, particularly when it is borne in mind that clipping rates would increase with feeding rates, other factors being equal.

\section{Conclusions}

Each of the factors listed in Tables 36 affects the relative impact of a species. Grasshoppers that are early season developers and hence feed at their maximum rate earlier in the season would have a more immediate and direct impact on range production than intermediate or late-season developers because active growth of many forage species is in spring or early summer (Clarke et al. 1947). Of course, the immediacy of impact is also affected by a preference for green vegetation versus a preference for dried material.

A strong preference for grasses, particularly those of high forage value that are dominant in the plant community (Table 5), would have a major influence on damage potential. Using this criterion, all of the early developing species and all but one of the intermediate ( $M$. femurrubrum) and late season species ( $M$. dawsoni) would be damaging should they become abundant.

Examples abound of grasshopper densities increasing when range is overgrazed by cattle (Riegert and Varley 1973a, Hewitt 1977, Holmes et al. 1979). Anderson's (1964) data on habitat preferences (Table 3, final column) suggest that most of the potentially harmful species at our study sites would be favored if the range is overgrazed by cattle.

\section{Literature Cited}

Anderson, N.L. 1964. Some relationships between grasshoppers and vegetation. Ann. Entomol. Soc. Amer. 57:736-742.

Anderson, N.L., and J.C. Wright. 1952. Grasshopper investigations on Montana rangelands. Montana State College Agr. Exp. Sta., Tech. Bull. 486. $56 \mathrm{p}$.

Bailey, C.G., and P.W. Riegert. 1971. Food preferences of the dusky grasshopper, Encoptolophus sordidus costalis (Scudder) (Orthoptera: Acrididae). Can. J. Zool. 49:1271-1274.

Beirne, B.P. 1972. Pest insects of annual crop plants in Canada. IV. Hemiptera-Homoptera. V. Orthoptera. VI. Other groups. Mem. Entomol. Soc. Can. 85.73 p.

Bhatnagar, K., and R.E. Pfadt. 1973. Growth, density and biomass of grasshoppers in the short-grass and mixed-grass associations. U.S. Internat. Biol. Program. Grassland Biome, Tech. Rep. 225. 101 p.

Brooks, A.R. 1958. Acridoidea of southern Alberta, Saskatchewan, and Manitoba (Orthoptera). Can. Entomol. Suppl. 9. 92 p.

Clarke, S.E., J.A. Campbell, and J.B. Campbell. 1942. An ecological and grazing capacity study of the native grass pastures in southern Alberta, Saskatchewan, and Manitoba. Agr. Can. Pub. 738.31 p.

Clarke, S.E., E.W. Tisdale, and N.A.Skoglund. 1947. The effects of climate and grazing practices on short-grass prairie vegetation in southern Alberta and southwestern Saskatchewan. Agr. Can. Pub. 747. 54 p.

Criddle, N. 1933. Studies in the biology of North American Acrididae development and habits. Proc. World's Grain Exhibition and Conference, Canada 2:474-494

Gilbert, N. 1973. Biometrical interpretation. Clarendon Press, Oxford. 125 p.

Hewitt, G.B. 1977. Review of forage losses caused by rangeland grasshoppers. U.S. Dep. Agr., Agr. Res. Serv. Misc. Publ. 1348. 24 p.

Holmes, N.D., D.S. Smith, and A. Johnston. 1979. Effect of grazing by cattle on the abundance of grasshoppers on fescue grassland. J. Range Manage. 32:310-311.

Isley, F.B. 1944. Correlation between mandibular morphology and food specificity in grasshoppers. Ann. Entomol. Soc. Amer. 37:47-67.

Johnston, A., J.F. Dormaar, and S. Smoliak. 1971. Long-term grazing effects on fescue grassland soils. J. Range Manage. 24:185-188.

Mitchell, J.E. 1973. A model of food consumption by three grasshopper species as determined by differential feeding trials. Ph.D. thesis, Colorado State Univ., Fort Collins, Colorado. $165 \mathrm{p}$.

Mitchell, J.E., and R.E. Pfadt. 1974. A role of grasshoppers in a shortgrass prairie ecosystem. Environ. Entomol. 3:358-360.

Mulkern, G.B., K.P. Pruess, H. Knutson, A.F. Hagen, J.B. Campbell, and J.D. Lambley. 1969. Food habits and preferences of grassland grasshoppers of the North Central Great Plains. North Dak. Agr. Exp. Sta., Bull. 481.32 p.

Mukerji, M.K., R. Pickford, and R.L. Randell. 1976. A quantitative evaJuation of grasshopper (Orthoptera: Acrididae) damage and its effect on spring wheat. Can. Entomol. 108:255-270.

Newton, R.C., C.O. Esselbaugh, G.T. York, and H.W. Prescott. 1954. Seasonal development of range grasshoppers as related to control. U.S. Dep. Agr., Bur. Entomol. Plant Quarant., Pub. E-873. 18 p.

Parker, J.R. 1930. Some effects of temperature and moisture upon Melanoplus mexicanus mexicanus Saussure and Camnula pellucida Scudder (Orthoptera). Mont. Agr. Exp. Sta. Bull. 223. 132 p.

Putnam, L.G. 1962a. The damage potential of some grasshoppers (Orthoptera: Acrididae) of the native grasslands of British Columbia. Can. J. Plant Sci. 42:596-601.

Putnam, L.G. 1962b. Experiments with some native and introduced plants as foods for Camnula pellucida (Scudd.) (Orthoptera: Acrididae) in Western Canada. Can. J. Plant Sci. 42:589-5y5.

Reichle, D.E. 1968. Relation of body size to food intake, oxygen consumption, and trace element metabolism in forest floor anthropods. Ecology 49:538-542.

Riegert, P.W. 1968. A history of grasshopper abundance surveys and forccasts of outbreaks in Saskatchewan. Mem. Entomol. Soc. Can. 52. 99 p.

Riegert, P.W., and J.L. Varley. 1973a. Above-ground invertebrates; II. Population dynamics and biomass production of grasshoppers. Can. Comm. Internat. Biol. Progr., Matador Project. Tech. Rep. 16. 134 p.

Riegert, P.W., and J.L. Varley. 1973b. Above-ground invertebrates: III. Bioenergetics of grasshoppers. Can. Comm. Internat. Biol. Prog., Matador Project, Tech Rep. 17. 81 p.

Smoliak, S., R.A. Wroe, and A. Johnston. 1976. Alberta range plants and their classification. Alta. Agr., Agdex 134/06. 7 p.

Ueckert, D.N., R.M. Hansen, and C. Terwilliger. 1972. Influence of plant frequency and certain morphological variations on diets of rangeland grasshoppers. J. Range Manage. 25:61-65.

White, R.M., and P.J.G. Rock. 1945. A contribution to the knowledge of the Acrididae of Alberta. Sci. Agr. 25:577-596. 